\title{
Standardowe i specyficzne rozumienie słowa rûh w tekstach Księgi Rodzaju i Księgi Wyjścia
}

\author{
Typical and Specific Understandings of the Word rûa \\ in the Texts of Genesis and Exodus
}

\author{
JANUSZ LEMAŃSKI \\ Uniwersytet Szczeciński \\ lemanski@koszalin.opoka.org.pl, ORCID: 0000-0002-1512-997X
}

\begin{abstract}
Streszczenie: Analiza dokonana w tym artykule pokazuje, że zastosowanie słowa rûa dzaju i Wyjścia mieści się w ogólnych znaczeniach łączonych z nim także w innych księgach biblijnych. Słowem tym opisuje się więc tu wiatr, zawsze jednak widziany jako "narzędzie w ręku” Boga, używane podczas działań zbawczych na rzecz ocalenia życia w ogóle lub Izraela. Potem rûạ oznacza samo życie obecne w człowieku i stanowiące dar od Boga, który może zostać odebrany. Wreszcie rûaḥ oznacza również charyzmatyczna siłę, udzielaną przez Boga wybranym ludziom, i to, co wewnętrzne w wczłowieku, jego stany ducha oraz emocje. Każde z tych znaczeń ma swoją specyfikę, najbardziej widoczną zwłaszcza w tzw. prehistorii biblijnej (Rdz 1,2; 3,8; 6,3; 8,1).
\end{abstract}

Słowa klucze: rûa ḥ; wiatr; oddech; Duch Boży; wnętrze człowieka; charyzmat; boska inspiracja

Abstract: The analysis made in this article shows that the usage of the word rûa in Genesis and Exodus fits with the general meanings linked to the word in other books of the Bible. In general usage this word describes, first, wind, albeit seen as ,a tool in the hand' of God used during redemptive activities to save life, life in general or that of Israel. Next rûa means life, such as that present in a human being as a gift from God, which can be taken back. Finally, rûa h also means a charismatic strength given by God to chosen people, and that which is internal to man, his states of spirit and emotion. All of those meanings have their specificity, which is most clearly visible in so-called biblical prehistory (Gen 1:2, 3:8, 6:3, 8:1).

Keywords: rûa ḥ; wind; breath; Spirit of God; inner-being; charism; divine inspiration

W Biblii Hebrajskiej spotykamy pojęcie $r \hat{u}^{a} h \underline{378}$ razy. Dodać do tego potrzeba jeszcze 11 zastosowań w aramejskiej części Księgi Daniela. W Pięcioksięgu pojęcie to pojawia się 38 razy. Zauważalna jest jednak ciekawa dysproporcja. Nie znajdujemy go ani razu w Księdze Kapłańskiej i tylko dwa razy pojawia się ono w Księdze Powtórzonego Prawa. Ponadto w pozostałych trzech księgach słowo to rzadko pojawia się w tekstach prawnych ${ }^{1}$.

Najogólniej rzecz ujmując, hebrajskie pojęcie $r \hat{u}^{a} h$ wiąże się z ruchem powietrza i oznacza zwykle wiatr lub oddech². Od tych dwóch podstawowych znaczeń pocho-

Tengström, „rûah" 372.

Albertz - Wetsermann, „rûạ̣”, 726, 728. 
dzą wszystkie inne niuanse znaczeniowe. W relacji do Boga wiatr - fenomen pogodowy - staje się narzędziem w rękach Stwórcy, zaś boski oddech oznacza tchnienie życia. Pojęcie to pozwala autorom biblijnym tworzyć niematerialną więź pomiędzy Bogiem i człowiekiem, gdyż mowa jest w Biblii zarówno o $r \hat{u}^{a} h$ Boga, jak i o $r \hat{u}^{a} h$ człowieka, a nierzadko także o wzajemnej interakcji pomiędzy nimi. Opisuje się tym pojęciem boskie natchnienia, trwałe i te wyłącznie okolicznościowe, a wreszcie szczególne duchowe dary uzdalniające do niezwykłych postaw i czynów. W odniesieniu do człowieka oddaje się tym pojęciem również obecny w nim ożywczy pierwiastek. Potem także niefizyczne elementy jego osobowości ${ }^{3}$. Spora część z tych znaczeń jest do odnalezienia również w zastosowaniach tego słowa w księgach Rodzaju i Wyjścia. Pośród nich można spotkać jednak także kilka interesujących i specyficznych niuansów.

Tak więc najczęściej słowo to stosowane jest w odniesieniu do wiatru, rozumianego zarówno jako fenomen naturalny, jak i zarazem narzędzie, którym Bóg się posługuje, aby okiełznać naturę i z jej pomocą interweniować w świat ludzi (Rdz 3,8; $8,1 ; \mathrm{Wj} 10,13.19 .21 ; 15,8.10)$. Do tej grupy wielu badaczy chciałoby zaliczyć również Rdz 1,2, ale kazus ten wymaga głębszej dyskusji, o czym poniżej. W tej grupie szczególnej uwagi wymaga również Rdz 3,8, którego tradycyjne tłumaczenie nie wydaje się oddawać w pełni teologicznego znaczenia tej wypowiedzi. Drugie często spotykane znaczenie to ożywczy oddech otrzymany od Boga, pierwiastek życia obecny w człowieku (Rdz 6,3.17; 7,16.22; 45,27). Kolejne powtarzające się znaczenie to natchnienie, uzdolnienie, specyficzny talent do wykonywania określonych rzeczy, rozumiany jako efekt bycia obdarowanym przez Boga (Rdz 41,38; Wj 28,3; $31,3 ; 35,31)$. Wreszcie ostatnia grupa to miejsca, w których słowo to dotyczy wnętrza człowieka, jego wewnętrznych przeżyć i emocji (Rdz 26,35; 41,8; Wj 6,9; 8,11; 35,21).

\section{Boski wiatr}

Zanim przyjrzymy się dwóm najbardziej intersującym w tym gronie fragmentom z Rdz 1,2 i 3,8, warto wcześniej zwrócić uwagę na trzeci w kolejności tekst z Rdz 8,1 oraz jego hiperboliczne powiązania teologiczne z tekstami znajdującymi się w Księdze Wyjścia.

3 Na ten temat szerzej Lemański, „Od Ducha Bożego”, 65-69. 


\subsection{Fenomen naturalny podległy władzy Stwórcy}

W Rdz 8,1b mamy niewątpliwie odniesienie do fenomenu naturalnego, jakim jest wiatr. Niemniej autor biblijny wyraźnie przypisuje Bogu wspomniane tu monumentalne poruszenie powietrza "nad ziemią" i łączy te Jego działanie $\mathrm{z}$ wolą ocalenia Noego oraz wszystkich innych żywych stworzeń zamkniętych wraz z nim w arce. Stwierdza się najpierw, że Bóg o nich „pamięta” (8,1a). W dalszej części tego wiersza egzegeci dostrzegają natomiast swoiste echo opisu z Rdz $1,2^{4}$. W istocie oba teksty przynależą do tej samej, kapłańskiej warstwy redakcyjnej, a sam potop w tej tradycji teologicznej Pięcioksięgu pojmowany jest jako swoiste cofnięcie efektów aktu stwórczego. Z kolei jego koniec to "nowe stworzenie”. Istotne jest tu wyakcentowanie faktu, że żywioły wodne, które na powrót spustoszyły wydobytą $z$ ich odmętów ziemię, zostają tu ponownie okiełznane z pomocą wiatru (por. Rdz 7,11; 8,2). Autor biblijny nie opisuje tu jeszcze jego siły, jakby chciał podkreślić, że Bóg wszystko czyni bez wysiłku. Sprawił po prostu, że wiatr „przeszedł” ('br Hifil) przez ziemię i żywioł się uciszył (por. Est 2,1: 7,10: w odniesieniu do gniewu), a wody pod wpływem tego wiatru opadły $\left(\check{s} k k \mathrm{Qal}^{6}\right)$. Interwencja ta jest kluczowa dla ocalenia życia na ziemi i zaowocuje już po potopie zawarciem uniwersalnego przymierza z Noem oraz ze wszystkim innymi żywymi istotami na ziemi (Rdz 9,8-17). W koncepcji kapłańskiej i post-kapłańskiej ( $\operatorname{Rdz} 6,3.17 ; 7,16.22)$ wszystkie żywe istoty mają ten sam oddech życia (w nie-P - Rdz 2,7 mowa była o nim tylko w odniesieniu do człowieka).

Analogicznie do interwencji Boga na rzecz Noego (protoplasta całej post-potopowej ludzkości; por. Rdz 10), w podobny sposób (z pomocą wiatru) i w podobnych okolicznościach, Bóg okiełzna potem morze, interweniując na rzecz Izraela (Wj 14,21; 15,8.10). Swoją władzę nad wiatrem ukazał On już jednak podczas serii

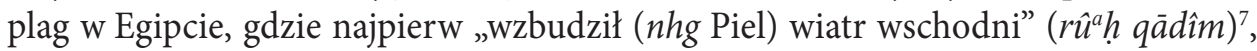
zsyłając na Egipt szarańczę (Wj 10,13), a potem - po interwencji Mojżesza - zepchnął ją do morza, dosłownie „zawracając” ( $h p k$ Qal) wiatr, określony tym razem jako „wiatr zachodni $\left(r \hat{u}^{a} h \underline{j}\right.$ jamm) bardzo mocny” (Wj 10,19). Oczywiście w realiach egipskich taki pustynny wiatr wiałby bardziej na linii południe-północ, a nie wschód-zachód, co zauważył i skorygował później - znający te realia $z$ autopsji - tłumacz Septuaginty. W każdym razie inwazja szarańczy - zjawisko często zachodzące w starożytnym Egipcie ${ }^{8}$ - zostaje tu powiązana od początku do końca z interwencją Boga posługującego się wiatrem. Tym razem o tej władzy Boga nad naturą opowiada autor niekapłański ${ }^{9}$.

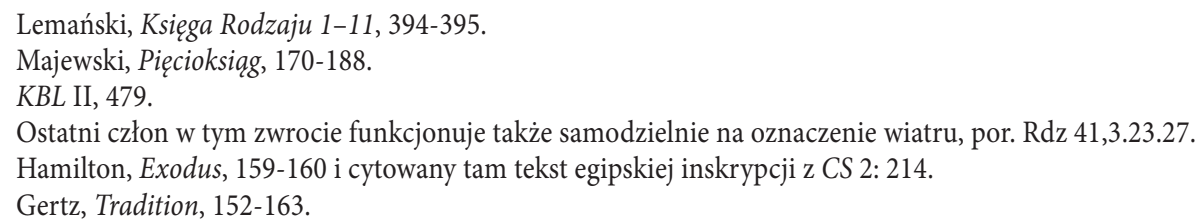


Apogeum władzy Boga nad wiatrem, wykorzystywanym jako instrument do zbawczych interwenci w obronie Izraela, osiągnięte zostaje jednak w spektakularnym wydarzeniu, jakim jest „osuszenie morza” (Wj 14,21). Ten sam niekapłański autor ${ }^{10}$ opowiada tu o „silnym ('azzâ) wschodnim wietrze”, który Jhwh zesłał, aby wiał całą noc i w konsekwencji osuszył morze. Ten instrumentalny aspekt wykorzystania wiatru zostaje tym razem podkreślony przez powiązaną z nim partykułę bĕ, nadającą całemu zwrotowi sens „za pomocą wiatru” lub „poprzez wiatr" ${ }^{11}$. Opis wydarzenia jest tu bardziej realistyczny niż w wersji kapłańskiej, w której morze rozstępuje się w jednej chwili i całe wydarzenie jest bardziej spektakularne. Tymczasem w nie-P cała sytuacja jest mniej dynamiczna i mniej cudowna. Autor niekapłański chce jednak przedstawić Jhwh jako władcę natury, który ujarzmia w iście „mitycznym stylu” pradawne żywioły (woda pojawia się często jako element przed-stwórczego chaosu) z pomocą innej siły natury, jaką jest wiatr. Ten motyw znany jest choćby ze starobabilońskiego eposu kosmologicznego Enuma eliš IV.42.13712, tym razem jednak zostaje w pewnym sensie "uhistoryczniony" i symbolicznie wykorzystany w opisie interwencji Jhwh w walkę stricte polityczną pomiędzy potęgami tego świata, reprezentowanymi przez Egipt, a narodem wybranym. Trzeba jednak zarazem zwrócić uwagę, że samo morze nie jest tu już pierwotnym przeciwnikiem Boga, jak w mitach mezopotamskich, a jedynie kolejnym - obok wiatru - narzędziem naturalnym, pozwalającym pokonać faraona i jego armię ${ }^{13}$.

W poetyckiej wersji tych wydarzeń „wiatr” określony zostaje już jako „tchnienie Twoich [Boga] nozdrzy" (ûběrúa ḥ appejkā) (Wj 15,8 również z partykuła bĕ w jej instrumentalnym sensie), a całe wydarzenie opisane słowami: „dmuchnąłeś z pomocą Twego wiatru/oddechu (nšp + běrûăḥkā) i przykryło ich morze...” (Wj 15,10). $\mathrm{W}$ ten sposób zlewają się tu w jedno dwa podstawowe znaczenia słowa $r \hat{u}^{a} h$, wiatr i oddech/tchnienie, a tło stanowi symboliczne odniesienie do wspomnianej walki $\mathrm{z}$ chaosem, który tym razem reprezentują nie naturalne żywioły, lecz siły polityczne (por. Ps 18,15; Ps 77,15-21; Iz 17,12-13; Na 1,3-4; Ha 3,10).

\section{2. Łagodny powiew wiatru ( $\mathrm{Rdz} 3,8)$ ?}

Wiatr często jest narzędziem Bożego sądu (por. Iz 27,8; 64,5; Jr 13,24; 18,17; Ez 13,13; Oz 13,15; Ps 11,6). W takim kontekście - zdaniem niektórych badaczy ${ }^{14}$ - można umieścić również realia opisane w Rdz 3,8. Scena, o której mowa, ma miejsce już po zerwaniu zakazanego owocu w Edenie, kiedy pojawia się tam

\footnotetext{
10 Lemański, „W poszukiwaniu”, 28-30.

11 KBL I, 101, nr 16: „wskazuje na środki lub narzędzia”. Podobnie Tengström, „rûaḥ”, 382.

12 Dyskusję o roli wiatru w kosmologiach mezopotamskich przedstawia dobrze Horowitz, Mesopotamian, 196-204.

13 Na ten temat szerzej Lemański, „W poszukiwaniu”, 31-33.

14 Tengström, „rûaḥ", 383-384.
} 
Jhwh i za chwilę zacznie On szukać ukrytego wśród drzew ogrodu człowieka. Uwagę zwraca tu najpierw fakt, że „boski ogród”, choć stanowi cząstkę boskiego świata, nie jest miejscem stałego pobytu Boga. Stwórca jedynie go okazjonalnie nawiedza ${ }^{15}$, co opisuje się nawet mniej jako doświadczenie Jego fizycznej obecności, a bardziej jako odgłos (qôl) Jego kroków (doświadczenie akustyczne). Ten stworzony przez Boga świat reprezentuje jednak ustalony przez Stwórcę porządek stworzenia, który teraz został naruszony przez umieszczonych w nim ludzi. Można zatem spodziewać się jakichś konsekwencji, co zapowiada pojawienie się Boga w tym miejscu i Jego reakcja na brak człowieka na ścieżce, którą podąża (por. Rdz 3,8b-9). Nas intryguje przede wszystkim specyfikacja okoliczności, w jakich się to nawiedzenie dokonuje. Autor biblijny (nie-P) pisze, że Bóg przechadzał się po ogrodzie lěr $\hat{u}^{a} h$ h hajjôm, co często tłumaczy się - znacznie upraszczając - w sensie „w chłodnej porze dnia” ${ }^{16}$. W istocie wieczorem $\mathrm{w}$ realiach palestyńskich często doświadcza się powiewu orzeźwiającej bryzy od strony Morza Śródziemnego. Autor biblijny jednak chce tu powiedzieć nam coś więcej, niż tylko zaznaczyć, że chodzi o dający ulgę po spiekocie dnia wieczór. W zrozumieniu jego intencji pomóc może uważna analiza słów i kontekstu.

Słowo qôl może mieć różne znaczenia, bowiem odnosi się do wielu różnych rodzajów dźwięków. Tak więc może opisywać „szmer łagodnego wiatru” (1Krl 19,12), głośne śpiewy (Wj 32,18), dźwięki trąb (Joz 6,5), a wreszcie wyładowania atmosferyczne, stanowiące zapowiedź sądu (Wj 9,23-24). Słuszna rzeczą jest więc ustalić za każdym razem właściwy kontekst, w którym mówi się o usłyszeniu tego dźwięku/ (od)głosu ${ }^{17}$. Ważne znaczenie dla zrozumienia, o jaki „rodzaj głosu” chodzi tym razem, ma właściwa interpretacja wspomnianego już zwrotu lěrû̉ h̆ hajjôm. Oba leksemy były już bowiem użyte we wcześniejszym kontekście. Słowo $r \hat{u}^{a} h \mathrm{w} \mathrm{Rdz} 1,2$, zaś jôm w Rdz 2,17. Pierwsze może oznaczać wiatr lub oddech/ducha, drugie zaś - (z rodzajnikiem) konkretny dzień. O pierwszym z tych słów mowa jest w kontekście opisującym sytuację poprzedzającą akty stwórcze Boga. Dzień zaś wspomniany wcześniej, to ostrzeżenie: „w dniu, w którym spożyjesz [owoc z zakazanego drzewa] z pewnością umrzesz". Wielu egzegetów słusznie sądzi, że pierwsze znaczenie całego zwrotu lěrûh hajjôm w obecnym miejscu stanowi - jak wspomnieliśmy - odniesienie do wieczornej bryzy schładzającej skutki dziennego skwaru. Sugeruje to tak zwane lamed-temporal ${ }^{18}$, które narzuca niejako rozumienie całego zwrotu w sensie „wietrzna (pora) dnia”, jego chłodniejsza część, a ta - w realiach Kanaanu - następuje wieczorem $^{19}$. Nigdzie jednak w Starym Testamencie, poza tym jednym miejscem, nie

\footnotetext{
15 Lemański, Księga Rodzaju 1-11, 248.

16 BT: „W porze, kiedy był powiew wiatru”; BWP: „podczas orzeźwiającego wiatru”; BG: „w powiewie dziennym”; BP: „,gdy wiał codzienny wietrzyk”; A. Kuśmirek: „przy powiewie dnia”; S. Łach: „w powiewie dziennym”; J. Lemański: „podczas [wieczornej bryzy] w ciągu dnia”.

17 Tak słusznie Walton, Genesis, 224.

18 Joüon, A Grammar $\$ 263-267$.

19 Collins, Genesis 1-4, $151+$ przypis 8 .
} 
spotykamy już więcej podobnej konstrukcji. Warto zatem spojrzeć na nią uważniej niż tylko z perspektywy realiów pogodowych panujących na konkretnym, nadbrzeżnym skrawku Kanaanu.

Wielu badaczy zauważa, że słowo $r \hat{u}^{a} h$, razem ze słowem qôl, pojawia się już potem tylko w opisach burzy (Jr 10,13; 51,16), gdzie oba słowa oznaczają odpowiednio „wiatr” i „pioruny”. Jeśli w obecnym miejscu do tego zestawienia dochodzi jeszcze słowo "dzień", to warto zastanowić się nad tym, czy teraz chodzi tylko o jego podstawowe i „neutralne” znaczenie (w sensie „jakaś określona, chłodna pora dnia”; tak LXX), czy raczej należy uznać, że nawiązując do Rdz 2,17, autor biblijny chce tu powiedzieć czytelnikom coś więcej.

Akadyjskie konotacje słowa jôm sugerują, że może ono przyjąć także sens „burza, silny wiatr”, czego śladem jest podobny sens, zachowany również w kilku miejscach Biblii Hebrajskiej (Pnp 2,17; 4,6; Iz 27,8; Sof 2,2) ${ }^{20}$. W tekstach akadyjskich słowo to w takim znaczeniu odnosi się do bóstwa przybywającego w „wichrze” na sąd. Obecny kontekst biblijny również sugeruje, że chodzi o początek sceny sądu. John Walton ${ }^{21}$ proponuje więc, aby całą wypowiedź tłumaczyć w sensie "They heard the roar of the LORD moving about in the garden in the wind of the storm". Jak zapobiegawczo stwierdza, nie musi to być ,jedyne słuszne” tłumaczenie ${ }^{22}$, zwłaszcza, że sens „burza” jest niezwykle rzadki w Biblii. Niemniej kontekst i konotacje obu pozostałych słów użytych w tej wypowiedzi mogą sugerować właściwy kierunek poszukiwań.

Sven Tengström ${ }^{23}$ proponuje jeszcze inne tłumaczenie, wydedukowane ze wskazanej przez siebie relacji do Rdz 2,17: „wiatr tego samego dnia”. Jak zauważa ten badacz, słychać tu „głos” Jhwh, ale nie widać samego Boga. Daje się słyszeć jedynie to, że On się przechadza (hlk participium w osnowie Hitpael) po ogrodzie. Zdaniem tego badacza, możliwe jest, że autorowi biblijnemu chodzi tu o sugestię, iż scena stanowi rodzaj manifestacji Boga w wietrze. Jednak $\mathrm{z}$ drugiej strony forma imiesłowu sugeruje, że czynność przechadzania się Boga to nie tylko quasi-poetyckie zastosowanie czasownika ruchu w odniesieniu do wiatru, poprzez który Bóg się manifestuje, ale i wskazanie, że chodzi o czynność regularnie powtarzaną przez Boga w tym miejscu. Wiatr ponadto nie jest $\mathrm{z}$ reguły elementem teofanii (por. Wj 19,16.19). Może być jednak, jak wspomnieliśmy, manifestacją gniewu Bożego i sądu. Faktem jest, że pobyt pierwszych ludzi w ogrodzie Boga nie był tożsamy ze stałym przebywaniem w Jego obecności, lecz przywilejem, dającym możliwość przebywaniem w Jego świecie (por. pierwotne przeznaczenie człowieka $[\operatorname{Rdz} 2,6]$ i powrót do niego po wydarzeniach

20 KBL I, 380; Walton, Genesis, 224.

21 Walton, Genesis, 224 ze wskazaniem na Niehaus, God, 155-159. Można tu dodać jeszcze wcześniejsze opracowania Niehaus („In the Wind”, 263-267), który z kolei wskazuje na Lust, „A Gentle”, 110-115.

22 Zabiegi lingwistycznie, by qôl tłumaczyć w sensie „thunder”, zaś lěr $\hat{u}^{a} h \underline{h}$ hajjôm „in the wind of the storm”, krytycznie ocenia m.in. Grundke, „A Tempest”, 548-551.

23 Tengström, „rûa ḥ”, 384: „the wind of very same day”. 
w Edenie opisany w Rdz 3,24). Kiedy porządek tego Bożego świata zostaje naruszony, Bóg czyni to, co będzie zwykł czynić w takich sytuacjach, daje usłyszeć swoją obecność i gotowość do sprawiedliwego osądzenia winnych tego stanu rzeczy.

\subsection{Rûa hoga w akcie stworzenia $(\operatorname{Rdz} 1,2)$}

Podstawowy problem w Rdz 1,2 dotyczy tego, jak tłumaczyć, w tym kluczowym dla całej Biblii tekście, słowo $r \hat{u}^{a} h$ ? Jednak nie mniejszy kłopot sprawia egzegetom również drugi człon w tym leksemie. $Z$ tego wynika nieustający dylemat i polaryzacja stanowisk. Jedni chcą bowiem tłumaczyć cały zwrot jako oddech lub Duch Boga, a inni raczej jako wiatr, albo nawet potężny wicher ${ }^{24}$. Mamy przed sobą bez wątpienia egzegetyczny crux interpretum.

Egzegeci są raczej zgodni, co do tego, że w. 2, w tak zwanym kapłańskim opisie stworzenia, przedstawia scenerię poprzedzającą same akty stwórcze ${ }^{25}$. To - rzec można - precosmic conditions wszechświata, swoisty preworld ${ }^{26}$ poprzedzający świat, jaki znamy. Na ten „przed-świat” składa się stan ziemi, określany zwrotem tōh $\hat{u}$ wābōhû, ciemność (hōšsek) i otchłań wód (těhôm). Zatem pierwsze pytanie, jakie się nasuwa, brzmi, czy rự ḥ ělōhîm „unoszący się nad powierzchnią wód” jest częścią tego stanu rzeczy, czy raczej już na początku relacji o stworzeniu wyznacza mu granice i zapowiada akty stwórcze?

W tradycjach kreacyjnych z Mezopotamii i Egiptu wiatr nie jest nigdy częścią pierwotnego chaosu. Stanowi raczej narzędzie pomagające go okiełznać bóstwu odpowiedzialnemu za wprowadzenie stwórczego porządku. Jeśli przyjmiemy zatem ten wariant także w odniesieniu do opisu biblijnego, a zarazem drugą opcję interpretacyjną, to pojawia się kolejne pytanie i zarazem wspomniany translatorski dylemat: czy słowo $r \hat{u}^{a} h$ rozumieć tu jako wiatr - narzędzie w „ręku” Boga, a potem jeszcze, czy dopełniacz ělōhîm intepretować jako superalivus? Czy może jednak mimo wszystko cały leksem rozumieć quasi-poetycko, jako oddech Boga, lub tradycyjnie, jako Ducha Bożego?

Większość egzegetów jest zdania, że mamy tu do czynienia z pewnego rodzaju metaforą reprezentującą jakiś rodzaj pierwotnej energii emanującej z Boga, która za chwilę zostanie wprzężona poprzez słowo Boga w Jego akty stwórcze (Ps 104,2b-4; por. Rdz 1,6-8: drugi dzień stworzenia: niebo i ziemia). Łatwo zauważalnym faktem jest bowiem to, że $r \hat{u}^{a} h$ nie odgrywa już potem żadnej roli w kontekście Rdz 1. Jeśli zaś zrozumiemy go jako oddech, a jeszcze lepiej, jako boską, kreującą i ożywiająca wszystko energię, to łatwiej zrozumieć nam kolejne etapy stworzenia, mające być

\footnotetext{
24 Na temat przyczyn, dla których dylematy translatorskie trudno rozwiązać, por. m.in. Luyster, „Wind”, 1-10; Smith, „A Semotactical”, 99-104; Janowski - Krüger, „Gottes Sturm”, 3-29.

25 Lemański, „Rdz 1,1-2,3”, 87-91.

26 Smith, The Priestly, 51.
} 
dokonywane za chwilę Bożym słowem i czynem. Przemawia za tym kolejne, ważne spostrzeżenie, które wynika z faktu, że ostatnia linia (w. 2c) różni się w opisie rzeczywistości od tej opisanej we wcześniejszych słowach (w. 2ab). Ciemność, ziemia

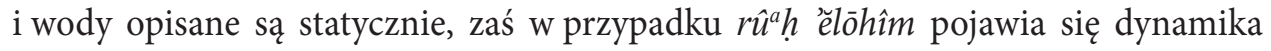
i ruch. „Unosi się" on, czy bardziej dosłownie, „fruwa” ponad wodami (mĕrahepet; participium Piel od $r h p$ ). Zastosowany czasownik opisuje aktywność fizyczną: lot, unoszenie się, szybowanie ponad czymś. Tak potem zostanie opisane unoszenie się ptaka nad swoim gniazdem (Pwt 32,11; por. KTU 1.18.IV; 21,31.32). Osnową Qal tego rdzenia (por. Jr 23,9) opisuje się „drżenie, potrząsanie”. Wielu badaczy dostrzega w tym czasowniku aluzje do starożytnych wyobrażeń o jakimś pierwotnym ,jaju” (taką rolę pełniłaby tu ziemia).

Jak zatem rozumieć różnicę pomiędzy statycznym i dynamicznym stanem pierwotnej rzeczywistości? Niektóre poetyckie teksty biblijne odzwierciedlają idee jakiegoś pierwotnego konfliktu pomiędzy Bogiem i siłami chaosu. Mowa jest w nich o poskromieniu morza lub reprezentujących go monstrów (Ps 89,11-13; 104,6-9; Hi 9,8; Hi 26,7-13, zwł. w. 12; Hi 38,1-11, zwł. w. 8; Jr 31,35). Ten konflikt to główny powód, dla którego mowa jest w tego rodzaju tekstach o użyciu siły w akcie stwórczym (Ps 65,7-8; Hi 26,12; Iz 66,1-2; Jr 27,5; por. też Am 5,8; 9,6). Można powiedzieć, że mamy tu odzwierciedlenie pewnej semickiej tradycji o pierwotnym, stwórczym konflikcie w świecie bogów, znanym chociażby ze starobabilońskiej opowieści o stworzeniu Enuma eliš. W Rdz 1,2 nie ma jednak żadnego konfliktu, a ciemność czy otchłań wód nie są tu żadną personifikowaną czy deifikowaną siłą, która byłaby w stanie przeciwstawić się Bogu - Stwórcy (por. Marduk i Tiamat). Dlatego też zrozumienie tego, co autor kapłański rozumie przez wspomniane precosmic conditions, wydaje się tu szczególnie ważne, jeśli chcemy odczytać sens leksemu rûa ḥ ělōhîm.

Autor kapłański nie zajmuje się jeszcze późniejszym problemem tzw. stworzenia wszystkiego ex nihilo (2Mch 7,28 ${ }^{27}$. Takich konotacji nie ma w każdym razie czasownik br', opisujący stwórczy akt Boga ${ }^{28}$. Jakkolwiek czasem mówi się w Biblii, że Bóg stworzył nie tylko światło, ale i ciemności (Iz 45,6-7; w Ps 104,2 światło już istnieje i nie trzeba go stwarzać; por. $\operatorname{Rdz} 1,3-5)$, oraz że w akcie stworzenia powstały również wody (Ps 148,4-5), to w Rdz 1,2 obie rzeczywistości (ciemności i otchłanie wód) wydają się stanowić pierwotny, istniejący jeszcze przed inicjacją procesu stwarzania, element rzeczywistości. Można sądzić, że zdaniem autor kapłańskiego istnieje już także ziemia. Na razie pokryta jest jednak wodami (por. Rdz 1,6-8.9-10). Nie jest to zatem nic (por. Mdr 11,17) ${ }^{29}$. Autorowi biblijnemu chodzi tym razem raczej o stan, w którym ziemia nie jest jeszcze zdatna do wegetacji oraz zamieszkania przez ludzi

27 Na temat tej idei por. Laskowski, Druga Księga Machabejska, 382-384; Majewski, Pięcioksiąg, 119-121.

28 Lemański, Księga Rodzaju 1-11, 146-148.

29 Komentarz do zwrotu „bezładna materia”, znajdującego się w tym tekście, por. Poniży, Ksiega Mądrości, 331-332. 
i zwierzęta (por. Rdz 1,2 i Rdz 2,5) ${ }^{30}$. Akcent pada tu zatem na fakt, że taka rzeczywistość, jaką opisuje się w w. 2, do niczego się nie nadaje, nie jest funkcjonalna i trzeba w niej dokonać istotnych rozgraniczen ${ }^{31}$, wyznaczyć konkretne funkcje.

Ciemność. Domeną, w której rozgrywa się akt stworzenia, są niebo i ziemia (Rdz 1,1; por. Am 9,5-6; Hi 9,8-9). Po zestawieniu „niebo i ziemia” (w. 1), pojawia się - na zasadzie polaryzacji względem Rdz 1,3 (stworzenie światła) - zestawienie „Ziemia - ciemność”. Struktura wiersza sugeruje, że ciemność - element początkowego stanu - to realia, w których manifestuje się rữ ĥ êlōhîm. Mamy zatem niezwykłe, jak na standardy biblijne, okoliczności dla teofanii (por. Ps 104,1b-2a) ${ }^{32}$. Być może w istocie chodzi tu o podkreślenie tej „niewidzialności” Boga w tym pierwotnym stanie świata i przygotowanie czytelnika do przyjęcia Jego objawienia się w dziele stworzenia ${ }^{33}$.

Ziemia już istnieje. Jakkolwiek w Rdz 1,1 stwierdza się, że została stworzona przez Boga, to wspominany już czasownik br' nie opisuje tworzenia czegoś z niczego, lecz tworzenie czegoś, co dotąd nie istniało w takiej formie, w jakiej zaistnieje w momencie swego stworzenia. Problemem ziemi jest jej aktualny, przed-stwórczy stan, opisany słynnym leksemem tōhû wābōhû. Tak opisana rzeczywistość wydaje się zajmować przestrzeń pomiędzy wodami górnymi i dolnymi, ale jest od nich zarazem niezależna ${ }^{34}$. W ostatnim czasie coraz częściej podkreśla się, że żadne z tych słów osobno $^{35}$ ani też oba w połączeniu ze sobą, nie oznaczają chaosu, choć tak właśnie najczęściej zbitkę tę interpretowano w minionym stuleciu ${ }^{36}$. Dlatego też większość tłumaczeń akcentuje raczej brak właściwej formy i tym samym odzwierciedla podejście ontologiczne w interpretacji tego leksemu. Wcześniejsze i późniejsze greckie tłumaczenia również akcentują raczej materialny punkt widzenia. LXX rozumie ten leksem w sensie „niewidoczna i niewyposażona (gr. akataskeuastos)”. Sens drugiego z greckich słów lepiej oddaje jego etymologiczny ekwiwalent: „niemożliwa do wyposażenia", przez co rozumie się, że nie tylko nie było na niej życia, ale też i warunków, aby ono w ogóle zaistniało ${ }^{37}$. Również św. Augustyn (Wyznania XII.22) rozumiał cały leksem w sensie „(ziemia była) niewidzialna i nieukształtowana”. Żadne z po-

30 Na temat strukturalnych powiązań pomiędzy Rdz 1, 2 i 2,5 por. Shea, „Literary”, 49-68. Na temat tzw. „abiotic concept od earth” por. Ouro, „The Earth [...] Part I, II, III”.

31 Majewski, Pięcioksiąg, 114-119.

32 Ouro, „The Earth [...] Part III", 65.

33 Wyatt, „The Darkness”, 546-552.

34 Blenkinsopp, Creation, 32.

35 Głównie pierwsze z tych słów, bo drugie występuje tylko 3 razy i zawsze z połączeniu z pierwszym: Rdz 1,2; Iz 34,11; Jr 4,23. Słowo tōh û występuje około 20 razy, z tego połowa w Iz 40-45 (Iz 24,10; 29,21; 34,11; $40,17 ; 40,23 ; 41,29 ; 44,9 ; 45,18.19 ; 49,4 ; 59,4)$, pozostałe wystąpienia to: 3 razy w Księdze Hioba (Hi 6,18; $12,24 ; 26,7)$ i po razie w Jr 4,23; 1 Sm 12,21; Pwt 32,10; Ps 107,40.

36 Tsumura, Creation, 22-35; Watson, Chaos, 16-17.

37 Popowski, Septuaginta, 5, przypis 2. Inne warianty mają nie mniej materialny charakter: Aquila: kenōma kai outhen; Theodozion: then kai outhen; Symmach: argon kai adiakriton. 
zostałych biblijnych zastosowań słowa tōhû nie sugeruje jednak, aby chodziło o brak formy odpowiedniej do życia. Kontekst dla tego słowa stanowi zawsze jakaś przestrzeń geograficzna, odniesienia do narodów, miast, ludów lub idoli. W relacji do nich tōhû akcentuje ich nieproduktywność, brak przydatności lub celu ich istnienia. Zdaniem Waltona ${ }^{38} \mathrm{w}$ tłumaczeniu tego hebrajskiego słowa najbardziej adekwatny byłby egipski leksem i koncepcja oddana przez niego jako "nie-istniejący”, co dobrze ilustruje zastosowanie analizowanego tu słowa w Hi 26,7:

„On rozpostarł (krainę) północy nad pustką,

ziemię zawiesił nad nicością" (tł. A. Tronina)

Słowo tōhû stoi tu paralelnie do słowa bělî-mâ („nicość), a „północ” (= miejsce spotkania nieba i ziemi, świata bogów i ludzi) w pierwszym stychu stanowi ekwiwalent dla słowa „ziemia” z drugiego stychu. Paralelne zestawienie sugeruje, że „pustka” rozpostarta jest nad wodami, które pokrywają jeszcze ziemię (por. Ps 24,1; 104,2-3; 136,6). Obraz sugeruje zatem nie tyle materialne nieistnienie, ile brak przydatności do czegoś. Według Waltona ${ }^{39}$ tōhû i bĕl-mâ oznaczają tu przed-stwórcze realia; pierwsze ze słów odnosi się do wód górnych, zaś drugie do wód dolnych (por. Rdz 1,6-8). $\mathrm{W}$ istocie ziemia wydaje się tu niezdolna do wygenerowania sama $\mathrm{z}$ siebie życia. Moim zdaniem nadal jednak chodzi tu o to, że nie ma ona odpowiedniej do tego formy, którą zyska dopiero w wyniku aktu stworzenia $(\operatorname{Rdz} 1,9-10)^{40}$, a nie tylko o brak wyznaczonego jej celu. Walton ${ }^{41}$ słusznie jednak zauważa, że w Biblii słowa tōhû używa się na opisanie zniszczenia porządku lub jakiejś cywilizacji (Jr 4,23). W tekstach egipskich taki stan rzeczy faktycznie oznacza „nie-istnienie”. Faraonowie często tak właśnie opisują koniec tych, których pokonali. Zdaniem Waltona dla autorów biblijnych tōĥि również stanowi swego rodzaju rzeczownik abstrakcyjny, odnoszący się do idei, słów, działań bez celu lub bez końcowych, oczekiwanych efektów. Ten stan rzeczy określa więc mianem „niefunkcjonalności”. Badacz ten odrzuca jednak rozumienie tego słowa w Rdz 1,2 w sensie, że ziemia była „bezpłodna/pustynna”' ${ }^{\prime 2}$ gdyż - jak zauważa - ziemia ma dopiero zostać wydobyta jako powierzchnia sucha (Rdz 1,9-10). Słowo chaos - w jego opinii - jest jednak „zbyt mocne” (too strong) i mylące (misleading idea), aby oddać ideę, jaką rzeczywiście kieruje się autor kapłański w swoim opisie stanu ziemi. Kolejność aktów stworzenia (Rdz 1,6-8: pojawienie się przestrzeni wolnej od opisanego powyżej stanu) sugeruje, że ta sytuacja

\footnotetext{
38 Walton, Genesis 1, 140-141.

39 Walton, Genesis 1, 143.

40 Lemański, Księga Rodzaju 1-11, 150. Tsumura (Creation, 35) tłumaczy tōhû w sensie „nieproduktywna”.

41 Walton, Genesis 1, 144.

42 Tak Tsumura (Creration, 33), wskazujący na brak zdolności do wegetacji. Na końcu (ibidem, 35) Tsumura rozumie jednak stan rzeczy jako „unproductive and uninhabited”.
} 
to efekt wypełnienia wszystkiego przez otchłań wód. To jej zatem trzeba wyznaczyć odpowiednie granice i dokładnie to za chwilę zacznie się dokonywać.

Wody (hebr. těhôm) nie są tu personifikowane, jak ma to miejsce w wyobrażeniach ludów Mezopotamii (Tiamat) i Egiptu (Nun). Autor kapłański nie musi ich także odzierać z boskości, bo nie podziela poglądów, w których siły natury byłby deifikowane lub choćby tylko reprezentowane przez bóstwa ${ }^{43}$. Żywioł ten nie stanowi tu nawet przeciwnika, z którym trzeba by walczyć. Chodzi wyłącznie o jeden z elementów geografii wszechświata, istniejący przed aktem stwórczym Boga. W procesie stwarzania zostaną one zepchnięte na obrzeża kosmosu, ograniczone mocą Boga i pozostaną pod Jego pełną kontrolą (patrz $\operatorname{Rdz} 7,11 ; 8,2$ : wody potopu). Starożytni różnie postrzegali to ograniczenie, wskazując, jako ich aktualny rezerwuar, Zatokę Perską, Ocean Indyjski, Morze Śródziemne czy jeziora Wan lub Urmia ${ }^{44}$. Dla autora biblijnego w każdym razie wody nie stanowią tylko prostego synonimu chaosu. Nie są też żadną siłą agresywną i przeciwstawną wobec Stwórcy. Same mają w sobie potencjał stwórczy, uruchamiany Bożym słowem (Rdz 1,20-21). Można zatem dostrzec tu pewną dwuznaczność w ich opisie. Część badaczy sugeruje, że być może hebrajskie těhôm pochodzi od tego samego semickiego rdzenia, co babilońskie imię pra-bogini Tiamat ${ }^{45}$. Tego jednak dowieść jest trudno. W tekście biblijnym ta „wodna otchłań” stanowi w każdym razie rzeczywistość, w której pogrążona jest, póki co, ziemia. W mitologii babilońskiej wody „pod niebem” nazywane są Apsu i stanowią domenę boga Enki (Ea). Nie wiemy, czy podobnie wyobraża sobie to autor kapłański, ale w innych miejscach również jest mowa o wydobyciu ziemi z tej otchłani wód poprzez stawianie granic morzu, pętanie chmur i rozpędzanie wód (Prz 8,29; Ps 104,8; Hi 26,6-8).

Czym lub kim jest zatem w realiach opisanych w Rdz 1,2ab rư $\hat{u}^{a}$ 'élōhîm? Leksem ten pojawia się 16 razy w Biblii Hebrajskiej (+ 5 razy w aramejskiej części Biblii ${ }^{46}$. Raz tylko występuje on w kapłańskim opisie stworzenia, a we wszystkich pozostałych zastosowaniach najbardziej adekwatny jego sens to "Duch Boży” ${ }^{4}$. Swego czasu pojawiła się propozycja, aby przynajmniej w niektórych z tych miejsc (por. Rdz 23,6; Ps 68,16; Iz 14,13) 48 $^{4}$ interpretować cały zwrot jako „boską" intensyfikację pierwszego członu (potężny, gwałtowny, straszliwy) ${ }^{49}$. Propozycja ta była dość popularna i czasem powraca się do niej także obecnie. Niemniej trzeba odnotować, że jednoznaczne wskazanie tego rodzaju interpretacji (ělōhîm wyłącznie jako

\footnotetext{
43 Tsumura, Creation, 46-57; Horowitz, Mesopotamian, 301-306, 332-333

44 Horowitz, Mesopotamian, 303.

45 Tak np. Blenkinsopp, Creation, 33.

$46 \quad \operatorname{Rdz} 1,2 ; 41,38 ; \mathrm{Wj} 31,3 ; 35,31 ;$ Lb 24,1; $1 \mathrm{Sm} \mathrm{10,10;11,6;16,15.16.23;18,10;19,20.23;} \mathrm{2Krn} \mathrm{15,1;}$ 24,20; Ez 11,24 + Dn 4,5.6.15; 5,11.14.

47 Hamilton, Genesis, 103, 111-114.

48 Blenkinsopp, Creation, 33, przypis 17.

49 Smith, „The Use”, 212-220.
} 
„an epithet of intensisty”) w którymkolwiek z tekstów zawierających ten leksem, nie jest wcale takie łatwe, by nie powiedzieć, że wręcz niemożliwe ${ }^{50}$. Gordon J. Wenham, słusznie zresztą, pyta o to, czemu słowo ělōhîm, które zawsze tłumaczy się w Rdz 1 jako „Bóg”, miałoby być w tym jednym przypadku traktowane wyłącznie jako superlativus ${ }^{21}$ Te uwagi skłaniają nas zatem do odrzucenia interpretacji całego leksemu jako wypowiedzi w rodzaju „najpotężniejszy wiatr”. Niemniej nadal pozostaje dylemat, czy optować mimo wszystko za tłumaczeniem pierwszego słowa w tym leksemie jako „wiatr”, czy raczej jako „oddech/Duch”?

W pierwszym przypadku zwolennicy zachowania interpretacji w sensie „wiatr” wskazują na to, że chodzi o element natury wykorzystany tu przez Boga i zarazem część opisywanego tu chaosu. Istotne znaczenie ma tu również fakt, że w tekstach ugaryckich słowo to ma wyłącznie sens „wiatr”. W drugim przypadku egzegeci wyrażają z kolei przekonanie, że jednak cały leksem odnosi się wyłącznie do Boga ${ }^{52}$. Być może w istocie autor biblijny chce tu zachować w pełni świadomie jakąś dwuznaczność. Z jednej strony zamierza przywołać wszystkie skojarzenia $\mathrm{z}$ wiatrem w roli narzędzia, którym Bóg się posługuje, a z drugiej jednak - wycieniować zbyt daleko idący, naturalny tylko charakter takich wyobrażeń i skierować uwagę czytelnika na niematerialne aspekty obecności Boga w materialnym świece? ${ }^{53}$ Taki wybieg interpretacyjny nie jest jednak chyba potrzebny. $\mathrm{W}$ istocie bowiem ani odniesienia do tradycji mezopotamskiej na temat roli wiatru w dziele stworzenia - o czym za chwilę - nie mają tu żadnego zastosowania, ani też sam wiatr i bez tych odniesień nie pełni potem żadnej roli w opisie biblijnym (por. jednak Ps 104,3: wiatr jako rydwan Boga). Jeśli zaś myślimy o „oddechu” Boga, to jego powiązanie z wypowiadanym przez Niego stwórczym słowem nasuwa się tu na myśl w sposób oczywisty (por. Ps 33,6-7) ${ }^{54}$.

Wiatr - owszem - odgrywa ważną rolę w mezopotamskich opowiadaniach o stworzeniu. O podobnej jego roli w niektórych fenickich wyobrażeniach o stworzeniu dowiedzieć się można także z późnych, greckich źródeł (Filon z Byblos, Praep. ev. 1.10.1 $)^{55}$. Takie tłumaczenie słowa $r \hat{u}^{a} h \mathrm{w} \mathrm{Rdz} 1,2$ sugeruje również Targum Onkelos i niektórzy rabini (np. Rabbi Ibn Ezra) ${ }^{56}$. Jeśli przyjąć, że tekst biblijny jest

50 Thomas, „A Consideration”, 209-224.

51 Walton, Genesis, 17. Podobnie Day, From Creation, 10.

52 Zwolenników pierwszej i drugiej interpretacji wymienia m.in. Ouro, „The Earth [...] Part III” $61+$ odpowiednio przypis 15 i 14.

53 Agustinus Gianto („Historical”, 1566) nie znajduje odpowiedniego słowa w języku angielskim, by tę „Zamierzoną" - jak uważa - dwuznaczność wyrazić. W języku angielskim najbliżej tego jest, w jego opinii, dwumian „life-breath”. Creation, 128, 142. Smith (The Priestly, 55) pisze, że tłumaczenie w sensie "wiatr” „conveys the natural side of the action, while 'breath' capture the divine anthropomorphism here". 
w jakiś sposób zależny od tradycji mezopotamskiej czy - szerzej - semickiej ${ }^{57}$, to należy przyjąć sens ,wiatr" również w biblijnym opowiadaniu o stworzeniu. W istocie w Enuma eliš wielokrotnie jest mowa - jak już wcześniej wspomnieliśmy - o instrumentalnym wykorzystaniu wiatru. Najpierw to Anu wykorzystuje cztery wiatry w swej walce przeciwko Tiamat. Mezopotamski tekst traktuje te wiatry jako stworzone wcześniej niż reszta uniwersum (I, 104-105). Kiedy potem Marduk dobija Tiamat, także pomagają mu w tym te same wiatry (IV, 42-43). Tworzy też Imhullu, „zły wiatr. Wiatr burzy i Huragan - Wiatr poczwórny. Wiatr siedmiokrotny, Wirowy i Wiatr, któremu nie sposób się oprzeć” (IV, 45-46; tł. J. Bromski). W końcu wpuszcza go w usta pokonanej Tiamat (IV, 96-99). Ostatecznie też „wiatr północny” na jego rozkaz przenosi resztki bogini w tajemne miejsce (I, 132). Wniosek, jaki płynie z tego spojrzenia na tekst $z$ Mezopotamii, może być tylko jeden. Nie trudno zauważyć, że wszystko to nie ma nic wspólnego z opisem zawartym w Rdz $1,2^{58}$.

W pozabiblijnych tekstach kreacyjnych wiatr nie stanowi w każdym razie części przed-kosmicznego stanu rzeczy. Nie jest deifikowany, ani personifikowany, jak ma to miejsce w Rdz 1,2, ale za to służy jako narzędzie, którym bóstwo dotyka wód chaosu w agresywny sposób (Enuma eliš 1,105-110), co z kolei nie ma miejsca $\mathrm{w} \operatorname{Rdz} 1^{59}$. Mimo to wielu badaczy chce pozostać przy takim rozumieniu słowa $r \hat{u}^{a} h$ w Rdz 1,2. John Day ${ }^{60}$ jest na przykład zdania, że czasownik „fruwać, latać” lepiej pasuje do wiatru niż do oddechu/Ducha Bożego (paralelnie do Rdz 8,1). Koronny argument, według niego, to Ps 104,3, gdzie opisuje się Jhwh jadącego na skrzydłach wiatru zanim jeszcze rozpocznie się stworzenie. Day jest zdania, że wiatr jest tu opisywany tak, jakby miał formę ptaka. Takie proste zestawienie tekstu poetyckiego z narracyjnym ${ }^{61}$, do tego zignorowanie faktu, że oba teksty jednak różnią się także pod wieloma innymi względami ${ }^{62}$, nie upoważnia do tak jednoznacznych wniosków. Tym bardziej że Day pisze przy tej okazji o pierwotnym konflikcie z wodami otchłani, co w żaden sposób nie wynika z opisu zawartego w Rdz 1,2. Wątpliwa jest też konkluzja, że czasownik „fruwać/unosić się” lepiej pasuje do wiatru niż do „ducha” ${ }^{\text {. }}$.

W tekstach, w których mowa jest o rî̀ hִ ělōhîm, chodzi zawsze o jakąś aktywność samego Boga lub jakiś aspekt Jego odziaływania na ludzi ${ }^{64}$. Dlatego badany

57 Tak argumentuje m.in. Orlinsky, „The Plain”,174-182. Por. też dyskusje w: Horowitz, Mesopotamian, 196204.

58 Ouro, „The Earth [...] Part III”, 62.

59 Walton, Genesis 1, 146. Badacz ten akcentuje jako zasadniczą różnicę fakt, że w Rdz 1,2 rûa ḥ êlōhîm, poprzez swój modyfikator (drugi człon leksemu), jest właśnie deifikowany i personifikowany zarazem, a w tej sytuacji cała koncepcja bardziej - jego zdaniem - pasuje do koncepcji egipskich niż mezopotamskich.

60 Day, From Creation, 9-10.

61 Lemański, „Rdz 1,1-2,3”, 72-74.

62 Lemański, „Rdz 1,1-2,3”, 82-84.

63 Odwrotni niż Day konkluduje swoją analizę np. Collins, Gensis 1-4, 45 (ze wskazaniem na Mt 3,16: Duch = gołębica).

64 Moscati, ,The Wind”, 308. 
przez nas leksem o wiele prościej jest odnieść do samego Boga niż do wiatru w roli boskiego narzędzia, a słowo ělōhîm potraktować nie tyle jako kwalifikator intensywności (potężny, największy), ile odniesienia do źródła stwórczej mocy ${ }^{65}$. Wyłączenie Boga $\mathrm{z}$ tego istotnego momentu, jakim jest konfrontacja z pierwotnym stanem rzeczywistości, byłoby dużym błędem. Michael DeRoche ${ }^{66}$, który zwraca uwagę na późniejszą aktywność Boga z pomocą „wiatru” w Rdz 8,1 oraz Wj 14,21, sądzi więc mimo wszystko, że w Rdz 1,2 nie chodzi o wiatr, ale o „creative activity of the deity”, a więc o czynnik, który nie jest częścią realiów opisanych w Rdz 1,2ab ${ }^{67}$, lecz stanowi aktywną już siłę od nich niezależną i nad nimi dominującą („unosi się nad..."), która dopiero za chwilę zostanie zaangażowana w te realia konkretnymi aktami stwórczymi. Mamy zatem przed sobą zwrot, który wyraża kontrolę Boga nad światem w jego przed-stwórczym stadium i zapowiada możność narzucenia przez Niego temu światu swej woli ${ }^{68}$. O takiej stwórczej roli $r \hat{u}^{a} h$ Boga czytamy na przykład w Hi 26,12-13:

Swą mocą ujarzmia morze,

Swą przebiegłością powala Rahaba

Jego tchnienie niebo rozświetla,

Jego ręka przebiła płochliwego węża (tł. A. Tronina)

Działanie Boga charakteryzują w tym tekście cztery elementy. Dwa pierwsze (moc i przebiegłość) to cechy dobrze wytrenowanego wojownika. Czwarty (ręka) to symbol siły i działania. Jeśli zachowamy paralelizm, podobnie jak w pierwszym stychu, to również trzeci element $\left(r \hat{u}^{a} h\right)$ powinien, tak samo jak czwarty, oznaczać siłę, działanie Boga. Podobne zestawienie można zauważyć zresztą w opisie aktywności Samsona, który posiadając „ducha” (Sdz 14,6.19; 15,14) danego przez Boga (Sdz 16,20), manifestuje go swoją nadzwyczajną siłą fizyczną (Sdz 16,5.9.15.17.19; por. też Sdz 3,10: $r \hat{u}^{a} h$ jako oznaczenie siły militarnej ${ }^{69}$. Cały zwrot implikuje zatem to, że działającym jest tu ów „oddech, Duch Boga” (Ps 18,16;33,6).

Tym razem opisaną w ten sposób aktywną obecność Boga odzwierciedla czasownik związany z obrazem ptaka unoszącego się nad gniazdem (por. Pwt 32,11). W tekstach syryjskich czy w ugaryckim eposie o Akhacie, czasownik ten akcentuje dodatkowo protekcję nad tym gniazdem, w którym znajdują się gotowe do wylęgu jaja ${ }^{70}$.

\footnotetext{
65 DeRoche, „The ruah”, 307; Tsumura, Creation, 74-76; Smith, The Priestly, 53.

66 DeRoche, ,The ruah”, 314-315.

67 DeRoche, „The ruah”, 318.

68 Ouro, „The Earth [...] Part III”, 65.

69 Smith, The Priestly, 53-54.

70 KBL II, 264; Epos ugarycki w tł. A. Troniny, „Eposy ugaryckie”, 608.
} 
Opis tego rodzaju - zdaniem Waltona ${ }^{71}$ - nie tylko pasuje do egipskich wyobrażeń o początkach wszechświata, ale i nie ma też w sobie nic wspólnego z potocznym rozumieniem chaosu ${ }^{72}$. Unoszący się nad otchłanią wód rữ $\hat{u}^{a}$ ẹ lōhîm pełni tu rolę nadzorcy nad przed-stwórczym stanem rzeczy, który za chwilę zaczną kształtować słowo Boga (por. Ps 33,6; 104,7; 147,18) i Jego „rzemieślnicze” działania. Chodzi zatem o stwórczą obecność Boga, jego immanentną manifestację na progu przed-stwórczej jeszcze rzeczywistości. „Unoszenie” się nad nią, to swoisty sposób opisania chwili oczekiwania na właściwy moment do działania. W tym sensie słowo $r \hat{u}^{a} \underline{h}$ najlepiej byłoby oddać jako „tchnienie” Boga, gdyż w grę za chwile wchodzić będzie zarówno słowo, którego wyartykułowanie nie jest możliwe bez oddychania (stąd oddech), jak i bardziej plastyczne czynności, które wymagają stwórczej energii, co sugeruje również tradycyjne tłumaczenie Duch Boga.

\section{Siła życiowa}

Rzeczownik rî́a hִ stanowi często również ekwiwalent słowa „żyć” (hājâ) i „życie (hajjîm). Opisuje siłę wewnętrzną, która decyduje o fizycznej witalności ${ }^{73}$. Taki aspekt znaczeniowy pojawia się w Rdz 45,27. Wcześniej była mowa o tym, że patriarcha Jakub na wieść o starcie ukochanego syna, Józefa, poczuł się jak ktoś schodzący do szeolu (por. Rdz 37,35). Teraz, nie tyle ze względu na słowa swoich synów, ile ze względu na widok wozów ofiarowanych przez Józefa, zaczyna wierzyć, że jego ukochany syn jednak żyje ${ }^{74}$. W efekcie wraca do niego życiowa siła. Mówiąc współczesnym językiem, chce mu się znowu żyć, odzyskuje ducha, co dobrze oddaje zastosowany tu zwrot: „ożył duch (wattěhî [ $[\rightarrow h j h] r \hat{u}^{a} h$ ) Jakuba, ich ojca”. Ten rodzaj wypowiedzi równie dobrze można by zaklasyfikować jako element opisów stanu ducha (por. Rdz 41,8: niepokój faraona).

71 Walton szczegółowo omawia to zagadnienie i dotyczące go teksty egipskie w: Genesis 1, 146-149, 151. Powołuje się na późny, demotyczny tekst kosmogonii egipskiej, oparty jednak na o wiele starszych koncepcjach (Papirus Carlsberg 5). Powiada się w nim o 8 bóstwach połączonych w jedno (Amun). Fragment 4 tego tekstu opisuje połączenie w jeden czterech wiatrów reprezentujących Amuna (jego niebiański oddech dotykający ziemi). Wiele egipskich tekstów opowiada potem także o separacji nieba i ziemi (Nut i Geb) dokonanych z pomocą tego wiatru przez bóstwo Szu (Słownik cywilizacji egipskiej, 173-174 [hasło „Kosmogonie”]). Po tym podziale mowa jest o uformowaniu lub zapłodnieniu kosmicznego jaja, z którego wykluwa się słońce (Ptah). Wiatr, który odgrywa tu istotną rolę, jest personifikowany w Tekstach Sarkofagów, wręcz traktowany jako ba (ekwiwalent hebrajskiego rứa h), należące do Szu i opisywane jako „podobne do oddechu” bóstwa. Określa się je również mianem „oddechu życia” (CS 2: 58). Owe ba ucisza dla Szu niebo i uspokaja ziemie. Chodzi o akty przygotowujące do stworzenie.

72 Walton, „Ancient”, 38-67.

73 Tengström, „rûa"̣̣”, 375.

74 Lemański, Księga Rodzaju 37-50, 340. 
W tekstach niekapłańskich mowa jest o ożywiającej sile przekazanej tylko człowiekowi (Rdz 2,7: nišmat hajjîm), która „z prochu ziemi” czyni „żywą/ożywioną istotę" (lenepeš hajjâ). Teksty (post)kapłańskie określają tę siłę życiową mianem $r \hat{u}^{a} h$ i przypisują ją także zwierzętom. Jej posiadanie pozwala odróżnić to, co żywe, o tego, co nie ma w sobie życia ( $\operatorname{Rdz} 6,3.17 ; 7,16.22)$. Trudność w sklasyfikowaniu źródłowym (P czy post-P) wynika $\mathrm{z}$ wielu różnych czynników, a przede wszystkim z niejasności natury krytyczno-literackiej. W przypadku Rdz 6,1-4 nie wiemy bowiem na pewno, co jest elementem jakiegoś starszego testu, a co jego redakcyjnym uzupełnieniem. Nie mamy zatem pewności jak datować poszczególne elementy przy takim rozróżnieniu. Niemniej przesłanie jest tu jasne. W Rdz 6,3 Bóg, ze względu na cielesny charakter człowieka (hû' bāśâr) i wynikającą z tego jego skłonność do grzechu (ww. 1-2), ustanawia granice ludzkiego życia $\left(120\right.$ lat $^{75}$ ), deklarując: „nie będzie pozostawa17 ${ }^{76}$ mój duch (rûhî) w człowieku [...]”. Słowo rû́ $\hat{u}^{a}$ wyraźnie odniesione jest tu do siły ożywiającej ludzkie ciało, a ta przypisana jest Bogu (por. Ps 104,29-30; Koh 12,7; Hi 34,14-15; Ez 11,19; 36,26; 37,1-10). Deklaracja może wynikać z faktu, że chodzi o naturalne ograniczenie, będące efektem bycia "także” istotą cielesną (por. Rdz 3,19), jak również stanowić konsekwencję przekroczenia kolejnych granic naruszających sfery właściwe poszczególnym bytom. Wydaje się, że tym razem (por. Rdz 3,1-6) to istoty niebiańskie ${ }^{77}$ naruszają granice nieba i ziemi. Kluczem do właściwego zrozumienia tej deklaracji jest jednak słowo jādôn. Nie ma on pewnego wyjaśnienia etymologicznego. W opinii podzielanej w ostatnich latach przez coraz większą liczbę badaczy ${ }^{78}$ należy go jednak łączyć $\mathrm{z}$ akadyjskim czasownikiem danānu - „być/stać się mocnym, silnym”. Jeśli uznać to rozumienie za właściwe dla Rdz 6,3, wtedy chodziłoby o to, że boski pierwiastek życia rozprzestrzenił się (umocnił się w człowieku) poprzez małżeństwa synów bożych z córkami ludzkimi, sprawiając, że potomstwo rodzące się z takich związków mogłoby zyskać nieśmiertelność. Ograniczenie ludzkiego życia, jak można sądzić przy takim rozumieniu tego słowa, to kolejna odsłona tematu znanego już z Rdz 3,22-2479. Niemniej w tekstach

75 Motyw znany także z tekstów z Emar: „120 lat to lata (życia) ludzkości - zaiste to jej nieszczęście”; Klein, „The 'Bane”, 59. Część badaczy uważa jednak, że chodzi o czas łaski do momentu, kiedy nastąpi potop (por. 4Q252,1.2-3 + żydowska tradycja interpretacyjna; Day, From Creation, 92). Na tym etapie narracji nie ma jednak jeszcze mowy o potopie, a tekst bardziej zamyka dotychczasowe wydarzenia, niż otwiera nowy etap opowieści; Lemański, Księga Rodzaju 1-11, 333-334.

Znaczenie użytego tu czasownika nie jest jasne; Lemański, Ksiega Rodzaju 1-11, 341; Day, From Creation, 87-89.

77 Na temat takiego rozumienia zwrotu „synowie Boży” por. Lemański, „Posłańcy”, 43-47.

78 Day, From Creation, 88, przypis 28.

79 Między innymi także z tego powodu Day (From Ceation, 91), w przeciwieństwie do większości badaczy, nie uważa w. 3 za późniejszą interpolację w oryginalnym tekście, lecz oryginalny element tekstu klasyfikowanego przez niego jako jahwistyczny. Niemniej Rdz 3,22-24 także nosi znamiona późniejszych dopowiedzeń do oryginalnego tekstu, a nawiązanie do tego tekstu w Rdz 6,3 nie musi automatycznie oznaczać tego samego czasu pochodzenia. Osobiście, w obu wypadkach, skłaniałbym się do tego, by uznać oba teksty za późniejsze uzupełnienia redakcyjne. 
genealogicznych przynależnych do P granice te osiąga się stopniowo (por. Rdz 5 i 11). Owa stopniowość może być zamierzona i nie musi stanowić dowodu, że istnieje brak koordynacji pomiędzy tekstami P i nie-P, jak sugeruje Day ${ }^{80}$. Jeśli do P (w mojej opinii raczej do post-P) należy także Pwt 34,7, to śmierć Mojżesza nie jest efektem starości (tak Abraham w Rdz 25,7-8 P), lecz skutkiem osiągnięcia wyznaczonej granicy życia.

Pozostałe wypowiedzi tego rodzaju są typowo kapłańskie. „Oddech życia” (rîa $h$ hajjîm) przypisuje się w nich wszystkim żywym stworzeniom, a nie tylko ludziom $(\operatorname{Rdz} 6,17 ; 7,15)$. Interesujący z punktu widzenia krytyki literackiej jest tu wariant z Rdz 7,22. Według tej wypowiedzi wszystkie żywe stworzenia posiadają „nišmat-rü $\hat{a}^{a}$ hajjîm w swoich nozdrzach". W opinii wielu badaczy chodzi tu o wyraźne połączenie koncepcji nie-P (Rdz 2,7: nišmat hajjî̀m + běappājw) z koncepcją $\mathrm{P}(\operatorname{Rdz} 6,17 ; 7,15$ : $r \hat{u}^{a} h$ hajjîm). Takie zestawienie mogłoby być zatem efektem późniejszej redakcji. Jeśli jednak w istocie chodzi tylko o lepsze uwydatnienie dychotomii: życie - śmierć (w. 22a vs. w. 22b) ${ }^{81}$, to równie dobrze autorem tej wypowiedzi może być także redaktor P, który miał już przed sobą teksty nie-P. W tej kwestii trudno o jednoznaczne rozstrzygnięcie.

\section{Charyzmat/inspiracja}

Charyzmatyczny wpływ ducha Bożego na rozmaitych bohaterów Starego Testamentu prześledzić można na przykładzie Księgi Sędziów. Niektórzy badacze uważają nawet, że jego zastosowanie w tej księdze jest przykładem najstarszego sposobu rozumienia całego zwrotu $r \hat{u}^{a} h$ 'e élōhîm/Jhwh i opisywanych nim uzdolnieńn ${ }^{82}$. Faktem jest, że ma on tu różne odniesienia i tylko czasem bywa łączony z okresowymi zdolnościami do skutecznego działania na rzecz wybawienia Izraela z obcego ucisku. To charyzmatyczne natchnienie i wzmocnienie ludzkich możliwości działania jest ograniczone w czasie.

Autorzy kapłańscy ${ }^{83}$ rozciągają ten dar także na szczególne uzdolnienia rzemieślnicze, które mogą być wykorzystane w pracach nad skonstruowaniem namiotu-świątyni u stóp Synaju (Wj 28,3; 31,3; 35,31). Najpierw Bóg rozkazuje Mojżeszowi, aby przemawiał do „wszystkich mądrych sercem, których Ja [Bóg] uzdolniłem/wyposażyłem duchem mądrości" (Wj 28,3; por. 35,35; 36,1). Mądrość dla starożytnych to przede wszystkim praktyczne umiejętności (por. Wj 35,25: tkaczki; Jr 10,9: złot-

\footnotetext{
80 Day, From Creation, 92.

81 Lemański, Księga Rodzaju 1-11, 392.

82 Tak Levine, „Religion”, 30-36.

83 Albertz (Exodus, 186, 247) zalicza te teksty do pierwszej wersji tekstu kapłańskiego oraz jego Vorlage.
} 
nicy; Ez 27,8; Ps 107,27: marynarze), a serce to desygnat rozumu, wolnej woli i wewnętrznych dyspozycji człowieka. Chodzi więc o ludzi, którzy z jednej strony mają możliwości i chęć wykorzystania swoich talentów rzemieślniczych dla pomnożenia chwały Boga (mają hōkmê lēb), a z drugiej o deklarację, że te ludzkie uzdolnienia i dobrą wolę Bóg niejako umacnia ( $m l$ ' Piel perfectum: „wyposażać/napełniać”) swoim $r \hat{u}^{a} h$ h hōkmâ. Chodzi najpierw o wszystkich mających "mądre serce” w Izraelu (por. Wj 35,10.25; 36,1-2), a potem o tych, których Bóg dodatkowo jeszcze uzdalnia swoim $r \hat{u}^{a} h$ (Wj 31,2-3; 35,31.35).

Mamy tu zatem deklarację, że Bóg uzdolnił niektórych „mądrych sercem” swoim „duchem mądrości” ${ }^{84}$. Dla starożytnych Izraelitów wszelka ludzka mądrość ma swoje ostateczne źródło w Bogu. W Wj 28,3 mamy zatem przed sobą krótki komentarz do sceny wybrania dwóch głównych wykonawców przenośnego sanktuarium, o których mowa jest w Wj 31,2-6. Tam bowiem identyfikuje się r $\hat{u}^{a} h \underline{h} h \bar{o} k m a ̂$ jako $r \hat{u}^{a} h$ h ělōhîm (Wj 31,3), używając jednak tego samego czasownika „wyposażyć/napełnić” ( $m l$ ' Piel imperfectum; tak samo jeszcze o jednym z nich: Besaleelu, pełniącym rolę nadzorcy nad budową namiotu-świątyni w Rdz 35,31.35). To jedyne miejsca w Księdze Wyjścia, w których mowa jest o „napełnieniu/wyposażeniu” kogoś duchem Boga. Co więcej, Besaleel to w ogóle pierwszy człowiek w Biblii napełniony takim duchem przez Boga ${ }^{85}$. W Księdze Rodzaju znajdujemy podobną deklarację faraona w odniesieniu do Józefa (Rdz 41,38). W obu wypadkach bohaterowie (Besaleel i Józef) zostają obdarzeni przez Boga jego natchnieniem/uzdolnieniem, niezbędnym do realizacji zadania, które wymaga pewnej kreatywności, wizji i umiejętności administrowania pracami tak, by przyniosły one zamierzony skutek.

W wielu innych miejscach Biblii obdarowanie „Duchem Boga/Jhwh” stanowi niezbędny ekwipunek uzdalniający obdarowanych nim do wykonania ich zadań (Lb 11,25-26; 24,2; 1Sm 10,10; 16,13). W obecnym miejscu mamy jednak do czynienia z wyraźną aluzją do „Ducha Bożego”, o którym mowa była w Rdz 1,2. Przekonuje nas do tego nie tylko rozpoznane już dawno ideowe i lingwistyczne powiązanie pomiędzy opisem stworzenia świata a budową świątyni ${ }^{86}$. Związek obu wydarzeń w obecnym miejscu podkreśla przede wszystkim zwrot kol-mĕlă kâ „wszelkie prace (rzemieślnicze)” (Wj 31,3; Rdz 2,3). „Duch Boży” uzdalnia zatem Besaleela do wykonania powierzonych mu zadań i stanowi źródło jego „mądrości” (hōkmâ), „rozumu” (těbûnâ), „wiedzy” (dảat) i „wszelkich prac rzemieślniczych” (kol-mĕlā’kâ). Wszystkie cztery określenia pojawiły się w odniesieniu do Hirama, który użył swych talentów do pracy w brązie podczas budowy świątyni Salomona (1Krl 7,13-14). Tradycja mądrościowa przekonuje potem, że wszystkie te dary pochodzą od Boga (Prz 2,6)

84 Van Pelt - Kaiser - Block, „rûaḥ”, 1075: „When rûah and heart are used together, the subsequent discussion typically consist of deliberary actions, not emotional descriptions".

85 Hamilton, Exodus, 483.

86 Na ten temat m.in. Majewski, Pięcioksiąg, 266-273. 
i On sam użył ich podczas stwarzania wszechświata (Prz 3,19-20) ${ }^{87}$. Aluzyjne odniesienie do Hirama stanowi jednak także krok do przodu, gdyż teologizuje naturalne talenty. O ile bowiem w przypadku Hirama mĕlā kâ oznaczało wyłącznie szczególne zdolności techniczne $(1 \mathrm{Krl} 7,14)$, to w obecnym miejscu ich posiadanie przypisuje się specjalnemu obdarowaniu ze strony Boga ${ }^{88}$.

Wróćmy teraz jeszcze na moment do wspomnianego już tekstu z Rdz 41,38. Znajdujemy w nim oświadczenie faraona, który komentuje zdolności Józefa. Nie tylko odczytał on właściwie przesłanie snów faraona, ale też wyciągnął z nich właściwe, praktyczne wnioski na przyszłość. Władca łączy te talenty Józefa $z$ faktem, że „duch Boży (rự hִ ělōhîm) jest w nim”. Zostaje on tu uznany równocześnie za człowieka nieporównywalnego z innymi, „bystrego i mądrego” (nābôn wĕhōkām) (Rdz 41,39; por. w. 33: w ustach Józefa). Z tych powodów zaraz potem Józef zostanie ustanowiony drugim człowiekiem w Egipcie (Rdz 41,40). Motyw łączący zdolności interpretowania snów, jako wyrazu specjalnych darów udzielonych przez Boga, nie jest właściwy tylko późnym tekstom Starego Testamentu (Dn 2; 4; 5). Znajdujemy go również w o wiele starszych fragmentach Biblii (Lb 24,2-4.16). Dlatego obecna wypowiedź faraona bywa zaliczona do najstarszych tekstów w Pięcioksięgu, w których zdolność ta uznawana jest za wyraz inspiracji charyzmatycznej ${ }^{89}$. W wypowiedzi faraona słowo êlōhîm nie ma bowiem rodzajnika i może mieć wydźwięk politeistyczny. Niemniej nie musi to jeszcze decydować o starożytności tekstu ${ }^{90}$. Równie dobrze może być elementem techniki opowiadania. Najważniejsze jednak jest to, że faraon nie ma tu na myśli jakiegoś chwilowego charyzmatu, lecz trwałe uzdolnienie, które czyni z Józefa najlepszego kandydata do sprawowania nowej funkcji polityczno-administracyjnej w Egipcie ${ }^{91}$.

\section{4. (Duchowe) wnętrze człowieka}

Znajdujemy wreszcie w dwóch pierwszych księgach Biblii wypowiedzi, w których słowo $r \hat{u}^{a} h$ odnosi się do wnętrza człowieka, jego przeżyć i emocji (Rdz 26,35; 41,8; Wj 6,9; 8,11; 35,21). Najpierw czytamy o stanie ducha Izaaka i Rebeki, którzy przeżywają "wewnętrzne zgorzknienie” (mōrat rư $\hat{u}^{a} h$ ) z powodu małżeństw Ezawa

\footnotetext{
87 Alexander, Exodus, 607-608.

88 Albertz, Exodus, 252 + przypis 10.

89 Tengström, „rûaḥ”, 391-392. Przy okazji deklaracja ta to zarazem uznanie wyższości takiej wiedzy inspirowanej prze Boga nad egipskimi technikami wyjaśniania snów; Baran, „Sny”, 86.

90 Obecną scenę z Rdz 41 można równie dobrze uznać za element doświadczenia związanego z diasporą egipską po inwazji babilońskiej na Judę; tak Amit, „Travel”, 237.

91 Lemański, Ksiega Rodzaju 37-50, 206.
} 
$\mathrm{z}$ córkami synów Cheta (Rdz 26,35). Słowo mōrâ w połączeniu ze słowem $r \hat{u}^{a} h$, jak tu, lub z nepeš (Prz 14,10) opisuje wewnętrzną ",gorycz, zgryzotę"92.

Podobne przeżycia wydają się dotykać również faraona, który reaguje na swoje sny "niepokojem swego ducha” (wattiqqem [ $\rightarrow$ p'm Nifal] rûhhô) (Rdz 41,8). Tym razem wewnętrzny stan faraona opisuje rdzeń czasownikowy wyrażający niepokój, zmartwienie (por. Ps 77,5; Dn 2,3; w kontekście snów lub bezsenności) ${ }^{93}$.

Jeszcze inny aspekt wewnętrznego udręczenia znajdujemy w opisie reakcji Izraelitów na powtórną misję Mojżesza. Po swoim „drugim” powołaniu oznajmia on im słowa Jhwh. Ci jednak nie chcą już go słuchać z powodu „udręki ducha” (miqqōṣer $\left.r \hat{u}^{a} h\right)\left(\mathrm{Wj}\right.$ 6,9). Przy dosłownym tłumaczeniu chodzi o „krótkość rî̀ $\hat{a}^{a}$ ”. Rzeczownik qōṣer jest bowiem pochodną rdzenia qșr „być krótkim”. Jego połączenie z r $\hat{u}^{a} h \underline{h}$ (Mi 2,7; Hi 21,4; Prz 14,29) i z nepeš (Lb 21,4; Sdz 10,16; 16,16; Za 11,8) oznacza „krótki oddech”, co tworzy kontrast dla zwrotu 'erek 'pjm - „długi oddech” (Prz 14,29; por. Prz 14,17; Koh 7,8). Tego rodzaju zwrot pojawia się jedynie w obecnym miejscu, choć porównywalne idiomy znaleźć można potem także gdzie indziej (wspomniane już teksty Hi 21,4; Mi 2,7). Dokładne znaczenie tego leksemu nie jest pewne. Może oznaczać zarówno przygnębienie, jak i niecierpliwość (tak LXX). Obecny kontekst sugeruje raczej to pierwsze rozumienie ${ }^{94}$, czyli skutki wzmożenia ucisku ze strony Egipcjan. Nie można jednak wykluczyć także negatywnej reakcji (brak cierpliwości) na kolejną próbę podjętą przez Mojżesza, aby skonfrontować się z faraonem. Trzecia możliwość, zasugerowana przez Rasziego, to „krótki oddech”, w sensie „wyczerpanie/ zmęczenie". Także skutek ciężkiej, niewolniczej pracy.

Odwrotność opisanego powyżej stanu ducha może wyrażać, ukuty od rdzenia rwh („czynić przestrzennym”), rzeczownik hārěwāḥ̂. Opisuje się nim przerwę, wytchnienie po ustąpieniu jakiegoś obciążenia ${ }^{95}$. We współczesnym języku dobrze można oddać jego sens słowami „złapanie oddechu”. Tak przynajmniej sugeruje kontekst w Wj 8,11. Precyzyjne wyjaśnienie sensu tego niezwykle rzadkiego rzeczownika nie jest jednak takie proste. Pojawia się on bowiem jeszcze w Lm 3,56, gdzie podane powyżej znaczenie nie do końca pasuje w tamtym kontekście. Niemniej sens „ulga" ${ }^{\prime \prime 6}$ lub „wytchnienie" ${ }^{97}$ wydaje się tu najbardziej adekwatny.

Wreszcie w Wj 35,21 spotykamy ponownie znane nam już połączenie „serce i duch". Tym razem chodzi o opisanie woli finansowego partycypowania wszystkich Izraelitów w budowie namiotu-świątyni. Okazuje ją „każdy, kogo skłoniło (nś) jego serce i każdy kogo pobudził ( $n d b)$ jego duch". Zestawienie to, jak pamiętamy, ozna-

\footnotetext{
92 KBL I, 595.

93 KBL II, 39.

94 KBL II, 188-189; Tak też Houtman, Exodus, 56, przypis 137; 505: „, because their spirit had been broken by the relentless forced labour"; por. Dohmen, Exodus, 191; Alexander, Exodus, 128-129.

95 KBL II, 250.

96 Berges, Klagelieder, 223.

97 Dohmen, Exodus, 221.
} 
cza konkretne i w pełni świadome działania. Tym razem jednak rự ha nie wyraża inspiracji zewnętrznej, pochodzącej od Boga, lecz wewnętrzną. Akcent pada tu na fakt, że lud nie musiał być przymuszany do ofiarności, lecz czynił to z własnej woli i z ochotą. Taki jest podstawowy sens czasownika $n d b^{98}$, który w tekstach kapłańskich i Księgach Kronik poszerza swoje znaczenie z dobrowolnej ofiary na wszelki rodzaj dobrowolnej darowizny na rzecz świątyni (Wj 25,2; 35,21.29 Qal) ${ }^{99}$. W połączeniu $\mathrm{z} r \hat{u}^{a}$ h, słowem odnoszącym się tym razem do wewnętrznych, duchowych elementów w człowieku, wzmacnia się ten aspekt dobrowolności, akcentując wewnętrzną dyspozycję ze strony Izraelitów do wspomagania budowy namiotu-sanktuarium.

\section{Wnioski}

Analiza wypowiedzi zawierających pojęcie $r \hat{u}^{a} h$ w księgach Rodzaju i Wyjścia pozwala wnioskować, że sens tego słowa nie odbiega daleko od jego znaczenia w pozostałej części Biblii Hebrajskiej. W tekstach klasyfikowanych jako niekapłańskie słowo to oznacza często wiatr, zawsze jednak rozumiany, jako żywioł podległy woli Stwórcy i narzędzie w jego działaniach zbawczych na rzecz człowieka oraz innych żywych stworzeń (historia Noego) lub Izraela (Księga Wyjścia). W tekstach kapłańskich i późniejszych słowem tym określa się także siłę życiową lub pierwiastek życia obecny w człowieku, kojarzony z czynnością oddychania i mający swe źródło w Bogu. Znajdujemy w obu księgach wreszcie zastosowanie słowa $r \hat{u}^{a} h \mathrm{w}$ opisach charyzmatycznych uzdolnień, udzielanych wybranym ludziom przez Boga, i wewnętrznych stanów ludzkiego ducha oraz ludzkich emocji. Każde z zastosowań ma swoją specyfikę. W tym gronie odnaleźć można jednak także kilka niestandardowych zastosowań. Znajdują się one głównie w prehistorii biblijnej.

Najciekawsze $\mathrm{z}$ nich to Rdz 1,2, gdzie w interpretacji skłaniamy się raczej do boskich konotacji zwrotu rự ḥ êlōhîm, rozumiejąc przez te słowa próbę opisania sposobu niematerialnej obecność Boga na obrzeżach materialnej, przed-stwórczej rzeczywistości, w którą wkroczy On za chwilę poprzez swoje słowo i działanie. W ten sposób chce się również wskazać, że ich źródłem jest boski r $\hat{u}^{a} h$ h Drugi ciekawy tekst to Rdz 3,8, w którym kontekst i słownictwo sugerują nie tylko opis jakiego szczególnego momentu w ciągu dna, ale również wprowadzają realia przygotowujące czytelnika do sceny sądu nad pierwszymi ludźmi.

\footnotetext{
98 Conrad, „ndb”, 220.

99 Conrad, „ndb”, 222.
} 


\section{Bibilografia}

Albertz, R., Exodus 19-40 (ZBK.AT 2.2; Zürich: Theologische Verlag 2015).

Albertz, R. - Westermann, C., „r. $\hat{u}^{a} h$ Geist”, Theologisches Handwörterbuch zum Alten Testament, wyd. 4 (red. E. Jenni - C. Wetsermann) (Gütersloh: Kaiser 1993) II, 726-753.

Alexander, T.D., Exodus (AOTC 2; London: Apollos - Downers Grove, IL:, InterVarsity 2017). Amit, Y., „Travel Narratives and the Message of Genesis”, The Formation of the Pentateuch (red. J.C. Gertz et al.) (FAT 111; Tübingen: Mohr Siebeck 2016) 223-242.

Augustyn, Wyznania (tł. Z. Kubiak) (Warszawa: Pax 1987).

Baran, G., „Sny w opowiadaniu o Józefie egipskim”, Sny prorocze, sny wieszcze, objawienia Boże przez sny w tradycji starotestamentalnej (red. G. Baran) (Tarnów: Biblos 2017) 47-93.

Berges, U., Klagelieder (HThKAT) (Freiburg - Basel - Wien: Herder 2002).

Blenkinsopp, J., Creation, Un-Creation, Re-creation. A Discursive Commentary on Genesis 1-11 (New York: T\&T Clark 2011).

Clifford, R.J., Creation Account in the Ancient Near East and in the Bible (CBQMS 26; Washington, DC: Catholic Biblical Association of America 1994).

Collins, C.J., Genesis 1-4. A Linguistic, Literary, and Theological Commentary (Phillipsburg, NJ: R\&R Publishing 2006).

Conrad, J., „ndb”, Theological Dictionary of the Old Testament (Grand Rapids, MI - Cambridge: Eerdmans 1998) IX, 219-226.

Day, J., From Creation to Babel: Studies in Genesis 1-11 (LHBOTS 592; London et al.: Bloomsbury 2013).

DeRoche M., „The ruah 'lohim in Gen 1:2c: Creation or Chaos?”, Ascribe to the Lord. Biblical and Other Studies in Memory of Peter C. Craigie (red. L. Eslinger - G. Taylor) (JSOTSup 67; Sheffield: Sheffield Academic Press 1998) 303-318.

Dohmen, C., Exodus 1-18 (HThKAT; Freiburg - Basel - Wien: Herder 2015).

Enuma eliš czyli opowieść babilońska o powstaniu świata (opr. J. Bromski) (Wrocław: Bagiński 1998 [reprint wydania z 1925]).

Gertz J.C., Tradition und Redaktion in der Exoduserzählung. Untersuchungen zur Endredaktion des Pentateuch (FRLANT 186; Göttingen: Vandenhoeck \& Ruprecht 2000).

Gianto, A., „Historical Linguistics and the Hebrew Bible”, Studi sul Vicino Oriente Antico dedicati alla memoria di Luigi Cagni (red. S. Graziani) (Istituto Universitario Orientale, dipatrimeto di Studi Asiatici, Series Minor 61; Napoli: Istituto Universitario Orientale 2000) 1553-1571.

Grundke, C.L.K., „A Tempest in a Teapot? Genesis III 8 Again”, Vetus Testamentum 51/4 (2001) 548-551.

Hallo, W.W. (red.) The Context of Scripture. I. Canonical Composition from Biblical World (Leiden - Boston, MA: Brill 2003) (=CS).

Hamilton, V.P., The Book of Genesis 1-17 (NICOT; Grand Rapids, MI: Eerdmans 1990).

Hamilton, V.P., Exodus. An Exegetical Commentary (Grand Rapids, MI: Backer Academic 2011).

Horowitz, W., Mesopotamian Cosmic Geography (Mesopotamian Civilizations 8; Winona Lake, IN: Eisenbrauns 1998).

Houtman, C., Exodus (HCOT; Kampen: Kok 1993) I. 
Janowski, B. - Krüger A., „Gottes Sturm und Gottes Atem. Zum Verständnis von rư $\hat{u}^{a} h$ ’ělōhîm in Gen 1:1 und Ps 104,29f”, Jahrbuch für Biblische Theologie 24 (2009) 3-29.

Joüon, P., A Grammar of Biblical Hebrew (tł. i red. T. Muraoka) (Subsidia Biblica 14; Romae: Pontificio Istituto Biblico 1991).

Klein, J., „The 'Bane' of Humanity: A Lifespan of One Hundred and Twenty Years”, Acta Sumerologica 12 (1990) 57-70.

Koehler, L. et al. (red.), Wielki słownik hebrajsko-polski i aramejsko-polski Starego Testamentu (Warszawa: Vocatio 2008) I-II (= KBL).

Laskowski, Ł., Druga Księga Machabejska (NKB.ST 14/3; Częstochowa: Święty Paweł 2017).

Lemański, J., Księga Rodzaju. Rozdziały 1-11 (NKB.ST 1/1; Częstochowa: Święty Paweł 2013).

Lemański, J., Księga Rodzaju. Rozdziały 37-50 (NKB.ST 1/3; Częstochowa: Święty Paweł 2015). Lemański, J., „Od Ducha Bożego/Jhwh do Ducha Świętego”, Duch Święty (red. G.M. Baran J. Królikowski - P. Łabuda) (Scripturae Lumen 8; Tarnów: Biblos 2016) 63-84.

Lemański, J., „Posłańcy Boga oraz inne niebiańskie istoty w Księdze Rodzaju”, Studia Koszalińsko-Kołobrzeskie 21 (2014) 29-52.

Lemański, J., „Rdz 1,1-2,3 na nowo odczytane? Czyli pytanie o to, czy możliwe jest nowe spojrzenie na kapłański opis stworzenia?”, Studia Koszalińsko-Kołobrzeskie 23 (2016) 71-105.

Lemański, J., „W poszukiwaniu najstarszej literackiej wersji 'cudu nad morzem' (Wj 13,17-15,21)”, The Biblical Annals 6/1 (2016) 5-44.

Levine, B.A., „Religion in the Heroic Spirit: Themes in the Book of Judges”, Thus Says the Lord. Essays on the Former and Latter Prophets in Honor of Robert R. Wilson (red. J.J. Ahn S.L. Cook) (Library of Hebrew Bible/Old Testament Studies 502; New York: T\&T Clark 2009) 27-42.

Lust, J., „A Gentle Breeze or a Roaring Thunderous Sound?”, Vetus Testamentum 23/1 (1975) 110-115.

Luyster, R., „Wind and Water: Cosmogonic Symbols in the Old Testament”, Zeitschrift für die alttestamentliche Wissenschaft 93 (1981) 1-10.

Majewski, M., Pięcioksiag odczytany na nowo. Przesłanie autora kapłańskiego (P) i jego wpływ na powstanie Pięcioksięgu (Kraków: Uniwersytet Jana Pawła II - Wydawnictwo Naukowe 2018).

McClellan, W.H., „The Meaning of Ruah Elohim in Genesis 1,2”, Biblica 15 (1934) 517-527.

Moscati, S., „The Wind in Biblical and Phoenician Cosmogony”, Journal of Biblical Literature 66 (1947) 305-310.

Müller, H.-P., „Der Welt- und Kulturentstehungsmythos des Philon Byblios und die biblische Urgeschichte", Zeitschrift für die alttestamentliche Wissenschaft 112 (2000) 161-179.

Niehaus, J., God at Sinai (Grand Rapids, MI: Zondervan 1995).

Niehaus, J., „In the Wind of the Storm: Another Look at Genesis III 8”, Vetus Testamentum 44/2 (1994) 263-267.

Orlinsky, H.M., „The Plain Meaning of Ruah in Gen 1:2”, Jewish Quarterly Review 48 (1957/58) 174-182.

Ouro, R., „The Earth of Genesis 1:2: Abiotic or Chaotic? Part I, II, III”, Andrews University Seminary Studies 36 (1998) 259-276, 37 (1999) 39-53, 38 (2000) 59-67.

Poniży, B., Księga Mądrości (NKB.ST 20; Częstochowa: Święty Paweł 2012).

Popowski R., Septuaginta (Warszawa: Vocatio 2013). 
Rachet, G, Słownik cywilizacji egipskiej (tł. J. Śliwa) (Katowice: Księżnica 1994).

Sarna, N.M., Genesis (The JPS Torah Commentary; Philadelphia, PA: Jewish Publication Society 1989).

Shea, W.H., „Literary Structural Parallels Between Genesis 1 and 2”, Origins 16/2 (1989) 49-68.

Smith, J.M.P., „The Use of Divine Name as Superlatives”, American Journal of Semitic Languages 45 (1928-1929) 212-220.

Smith, M.S., The Priestly Version of Genesis 1 (Minneapolis, MN: Fortress 2010).

Smith, P.J., „A Semotactical Approach to the Meaning of the Term rî̀ $\hat{u}^{a}$ 'élōhîm in Genesis 1:2”, Journal of Northwest Semitic Languages 8 (1980) 99-104.

Thomas, D.W., „A Consideration of Some Unusual Ways of Expressing the Superlative in Hebrew", Vetus Testamentum 30 (1953) 209-224.

Tengström, S., „rûah", Theological Dictionary of the Old Testament (red. J. Botterweck et al.) (Grand Rapids, MI; Cambridge: Eerdmans 2004) XIII, 365-396.

Tronina, A. (tł.), „Eposy ugaryckie o Kerecie i Akhacie”, Ewangelia o królestwie (Scripturae Lumen 1; Lublin: Wydawnictwo KUL 2009) 563-621.

Tsumura, D.T., Creation and Destruction: A Reappraisal of the Chaoskampf Theory in the Old Testament (Winona Lake, MI: Eisenbrauns 2005).

Van Pelt, M.V. - Kaiser, W.C. - Block, D.I., „rûa ḥ”, New International Dictionary of Old Testament Theology \& Exegesis (red. W.A. VanGemeren) (London: Paternoster 1997) 1070-1078.

Walton, J.H., „Ancient Near Eastern Background of the Spirit of the Lord in the Old Testament", Presence, Power, and Promise. The Role of the Spirit of God in the Old Testament (red. D. Firth - P. Wagner) (Downers Grove, IL: InterVarsity Press 2011) 38-67.

Walton, J.H., Genesis (The NIV Application Commentary; Grand Rapids, MI: Zondervan 2001).

Walton, J.H., Genesis 1 as Ancient Cosmology (Winona Lake, MI: Eisenbrauns 2011).

Watson, R.S., Chaos Uncreated (Berlin: de Guyter 2005).

Wyatt, N., „The Darkness of Genesis 1:2”, Vetus Testamentum 43 (1993) 543-554. 